\title{
Social Cues-Customer Behavior Relationship: The Mediating Role of Emotions and Cognition
}

\author{
Nawras M. Nusairat ${ }^{1}$, Abdel Hakim O. Akhorshaideh ${ }^{2}$, Tahir Rashid ${ }^{3}$, Sunil Sahadev ${ }^{3} \&$ Grazyna Rembielak $^{4}$ \\ ${ }^{1}$ Faculty of Economics and Administrative Sciences, Applied Science Private University, Amman, Jordan \\ ${ }^{2}$ School of Business, University of Jordan, Amman, Jordan \\ ${ }^{3}$ Salford Business School, University of Salford, Salford, UK \\ ${ }^{4}$ Warsaw University of Technology Business School, Warsaw University of Technology, Warsaw, Poland \\ Correspondence: Nawras M. Nusairat, Faculty of Economics and Administrative Sciences, Applied Science \\ Private University, Amman, Jordan. Tel: 962-6-560-9999. E-mail:n_nserat@asu.edu.jo
}

Received: October 29, 2016 Accepted: December 13, 2016 Online Published: January 16, 2017

doi:10.5539/ijms.v9n1p1 URL: http://dx.doi.org/10.5539/ijms.v9n1p1

\begin{abstract}
This paper investigates the effect of social cues in a mall's shopping environment on customer behavior. Two competing mediation scenarios are assessed: emotion-cognition and cognition-emotion in a stimulus-organism-response (SOR)-based framework. Although the role of social cues in driving customer behavior in shopping contexts is largely addressed in the extant literature, the mechanism of the effect is still under-researched area and this study is an attempt to fill this gap.

The conceptual model is validated through a questionnaire survey of 1028 shopping mall customers from three cities in Jordan. Two different conceptual models are tested. The analysis reveals that the cognition-emotion mediated model is more robust in predicting the effect of social cues than emotion-cognition mediated model. The findings indicate that a) social cues have a significant positive effect on customers' emotion of pleasure; cognition; and behavioral response; and b) only pleasure and cognition mediate the effect of social cues on customers' behavioral response.

Theoretically, this study provides a comprehensive understanding of the mechanism by which customers' emotions and cognition mediate the effect of social cues on customer behavior; and practically, it asserts the significance of social cues as a marketing tool.
\end{abstract}

Keywords: social cues, emotion, cognition, shopping environment, customer behavioral response, structural equation modelling

\section{Introduction}

Rapid growth in the retail sector and the accompanying spectre of fierce competition imposes a greater burden on retailers in differentiating their retail offerings (Chen \& Hsieh, 2011). Retailers are also challenged by the emergence of more informed and sensitive customer segments (Im \& Ha, 2011). In this situation it is very clear that the role of traditional marketing tools such as merchandising and pricing is much diminished and often the shopping environment itself becomes a powerful tool of market differentiation and of gaining a competitive advantage (Baker, Grewal, \& Levy, 1992; Morrison, Gan, Dubelaar, \& Oppewal, 2011).

In a retail setting such as shopping malls, customers are naturally exposed to a large number of cues within the immediate shopping environment and which can be utilized to encourage better customer responses (Turley \& Milliman, 2000; Wakefield \& Baker, 1998). Besides the physical aspects involving the ambient and design factors, the social cues of the shopping environment such as personnel and other customers constitute vital components of the shopping environment (Baker, Grewal, \& Parasuraman, 1994).

The role of shopping environment in driving customers' responses has been substantially addressed in the marketing literature (Chebat, Michon, Haj-Salem, \& Oliveira, 2014; Donovan, Rossiter, Marcoolyn, \& Nesdale, 1994b; Kumar \& Kim, 2014; Lin, Baron, \& Daunt, 2016; Michon, Yu, Smith, \& Chebat, 2008; Shukla \& Babin, 2013; Walsh, Shiu, Hassan, Michaelidou, \& Beatty, 2011). However, the focus has been considerably limited to certain physical environment factors such as music (Sweeney \& Wyber, 2002), color (Chebat \& Morrin, 2007; 
Tantanatewin \& Inkarojrit, 2016), light (Quartier, Vanrie, \& Van Cleempoel, 2014), and scent (Chebat \& Michon, 2003; Leenders, Smidts, \& El Haji, 2016).

The role of social cues has been paid less attention. In this regard, Li, Ma, Zhao, \& Liu (2012) assert the need for further research on the role of social cues in servicescapes. Of the relatively limited research in this extent, the focus has been on certain social cues such as crowdedness (e.g., Machleit, Eroglu, \& Mantel, 2000; Uhrich, 2011), personnel (e.g., Klassen, Clayson, \& Jasper, 1996; Yan, Yurchisin, \& Watchravesringkan, 2011) and other customers (e.g., Brocato, Voorhees, \& Baker, 2012; Söderlund, 2011). In some other studies, social cues have been investigated as a part of a multi-environmental framework (e.g., Baker, Parasuraman, Grewal, \& Voss, 2002; Chen \& Hsieh, 2011; Lin \& Liang, 2011). Furthermore, a noticeable part of prior research has been conducted in laboratory settings such as simulated environments (e.g., Li, Kim, \& Lee, 2009; Yan et al., 2011), resulting in a less realistic findings.

Prior research on shopping environment cues in general has been largely based on the stimulus-organism-response (S-O-R) model proposed by Mehrabian \& Russell (1974). However, most of this research comprised either emotion or cognition as organism factors (Jang \& Namkung, 2009; Morrison et al., 2011). Together emotion and cognition as mediators are mostly investigated in studies addressing a single or few environmental stimuli (Chebat et al., 2014; Dennis, Michon, Brakus, Newman, \& Alamanos, 2012). Additionally, less research has considered the interplay mediating role of emotion and cognition on shopping environment-customers' behavior relationship (Kim \& Moon, 2009; Kumar \& Kim, 2014). Interestingly, in such a limited research, only one of the cognition-emotion or emotion-cognition hierarchies was considered (e.g., Kumar \& Kim, 2014; Laroche et al., 2005; Raajpoot et al., 2008), offering an interesting area of research. A simultaneous examination of such interactive role of customers' emotions and cognition while in a shopping environment is expected to provide unique understanding on how the social cues can be best utilized in encouraging better shopping behaviors.

In Jordan, a growing number of shopping malls are penetrating the Jordanian retail market (Akroush, Abu-ElSamen, \& Jaradat, 2011) as Jordanians increasingly are making a transition of shopping from traditional stores towards shopping malls (Khraim, Khraim, Al-Kaidah, \& Al-Qurashi, 2011). Although, the pleasant shopping environment is the most important factor underlying customers' switching towards shopping malls, there is still a deficiency of empirical evidence of customer buying behavior in shopping malls in Jordan. Keeping this knowledge gap in mind, this study investigates the effect of the social cues of a shopping environment in the context of Jordan on customers' behavioral response through examining two competing mediation scenarios; emotion-cognition and cognition-emotion.

\section{Research Significance and Expected Contributions}

The significance of the current study reveals from its expected theoretical and empirical contributions. From a theoretical standpoint, this study is expected to enrich the existing literature on the role of social cues of shopping environment in affecting customers' behavioral responses. This can be summarized in the following ways: firstly, unlike the majority of prior empirical studies (Jacob, Guéguen, Martin, \& Boulbry, 2011; Jani \& Han, 2014; Mehta, Sharma, \& Swami, 2013; Söderlund, 2011; Yan et al., 2011), this study examines the effect of social cues as a holistic concept rather than focusing on its individual components such as human crowdedness, employees, and other customers. Secondly, the present study uniquely integrates three different theories of customer behavior into one comprehensive framework to gain a greater understanding on how social cues affect customer buying behavior. Lastly, to our knowledge, this is the first study that simultaneously examines two competing scenarios of interplay mediation between emotions and cognition in the effect of holistic social cues on customer behavior. Thus, research findings are expected to provide distinctive insights into the mechanism by which customer emotions and cognition mediate the effect.

Empirically, the lack of empirical evidence on this topic in developing countries (e.g., Jordan) is of the main obstacles encountering national and international investors in the retail industry in general and shopping malls in particular (Akroush et al., 2011). Therefore, this study is believed to have a substantial practical significance to current and prospective mall operators in developing countries. The findings of the present study can provide insights into how to successfully project the social aspects of the shopping environment, and how they can be best utilized to stimulate better customers' responses. This in turn can largely contribute to enhancing a mall's competitiveness and profitability. 


\section{Theoretical Background and Research Hypotheses}

\subsection{The Mehrabian and Russell's Environmental Psychology Model}

Mehrabian \& Russell (1974) provide a valuable contribution to the body of knowledge through their model (known as M-R model), which is initially based on S-O-R environmental psychology paradigm. The term stimulus in the model refers to any factor having a changing impact on individuals' internal states (Vieira, 2012). However, when brought to consumer behavior research, a stimulus is then external to the individual and is either a marketing mix element or environmental input (e.g., social cues) (Bagozzi, 1986).

Organism represents the processing stage involving a set of perceptual, physiological, feeling and thinking activities that make up the emotional and cognitive states of the consumer (Koo \& Ju, 2010). According to the M-R model, three emotional states namely: pleasure, arousal, and dominance (PAD) capture the organism stage. Nevertheless, based on the lack of theoretical and empirical support for the role of dominance in predicting customers' behavioral responses (Donovan \& Rossiter, 1982; Russell \& Pratt, 1980), only pleasure and arousal dominated the vast majority of marketing studies adapting the model (Donovan, Rossiter, Marcoolyn, \& Nesdale, 1994a; Morrison et al., 2011; Ryu \& Jang, 2007; Sherman, Mathur, \& Smith, 1997; Walsh et al., 2011).

Response is the outcome in the causal chain of the M-R model. Mehrabian \& Russell (1974) depicted an individual's response towards an environment simply as approach or avoidance behaviors. Where approach behaviors reflect positive reactions toward a certain setting involving approaching it, remaining, exploring, interacting and holding a good impression and intention to revisit it again, avoidance behaviors imply the opposite. From a marketing perspective, a response can be referred to as "the final outcomes and the final decisions of consumers" (Chang, Eckman, \& Yan, 2011, p. 236), and is mainly operationalized using behavioral outcomes (Im \& Ha, 2011). Figure (1) shows the M-R model.

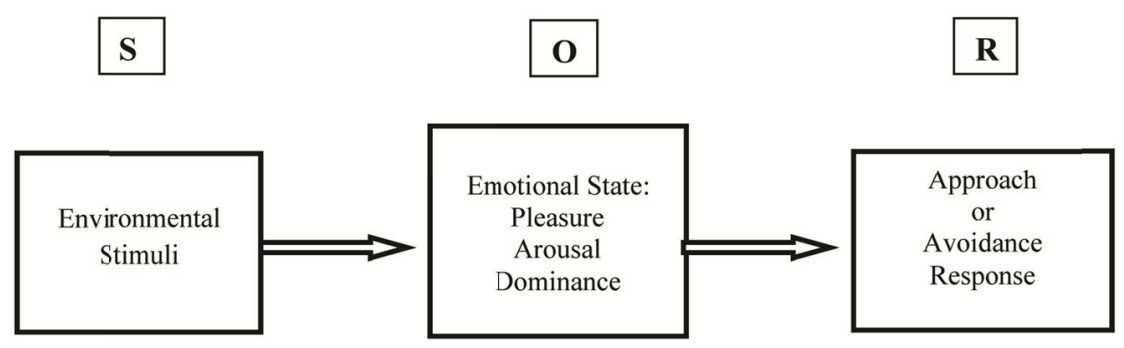

Figure 1. The Mehrabian-Russell's S-O-R Model

Note. Adapted from: Ryu \& Jang (2007, p. 59).

\subsection{Research Models}

This study examines two competing models incorporating both customers' emotions and cognition as interactive mediating variables in a (SOR)-based framework. The first model (figure 2) posits the social cues (S) to stimulate customers' emotions, affecting customers' cognitive evaluations of the environment $(\mathrm{O})$, which in turn influence customers' behavioral response (R). The flow of mediation in this model is hypothesized on the basis of "affect as information theory" or emotion-cognition approach (Zajonc \& Markus, 1984, 1985), which suggests that emotions are generated directly without forerunner cognitive processes. The second model (alternative model) (figure 3) posits that the social cues affect customers' cognitive evaluations of the shopping environment, eliciting customers' emotions, which in turn affect customers' behavioral response. The hierarchy of the mediation in this model is based on cognition-emotion approach (Lazarus, 1991), which suggests cognitive evaluation as a vital antecedent condition for emotions to elicit. 


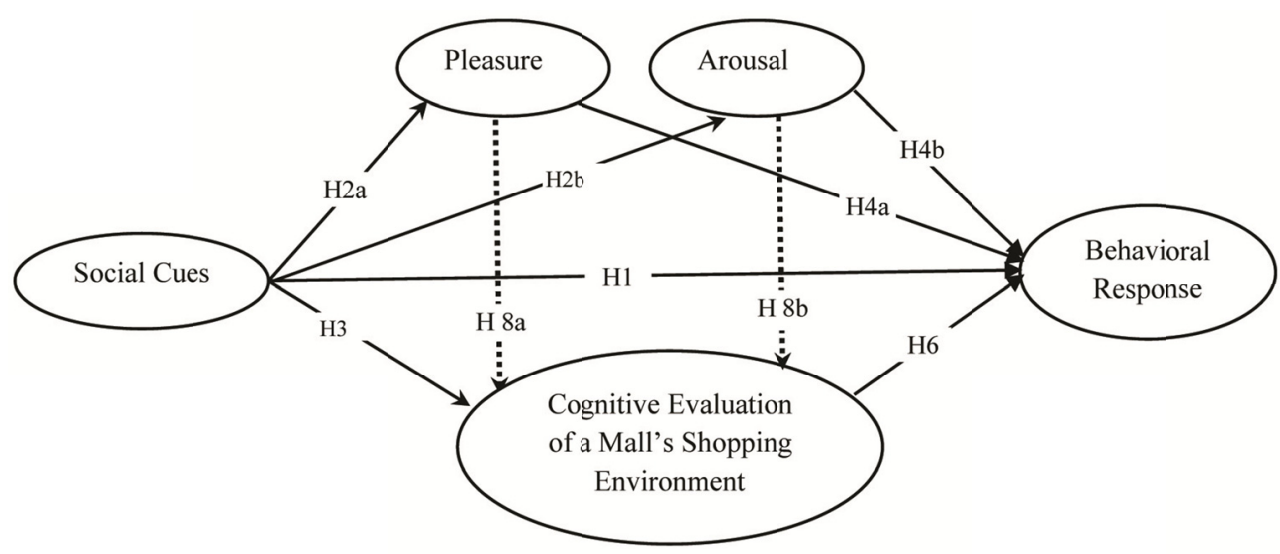

Figure 2. Model 1 Emotion-cognition mediated model

Note. Hypotheses 5, 7, 9, and $\mathrm{H} 9$ suggest mediation, thus, are not explicitly represented in the research conceptual model.

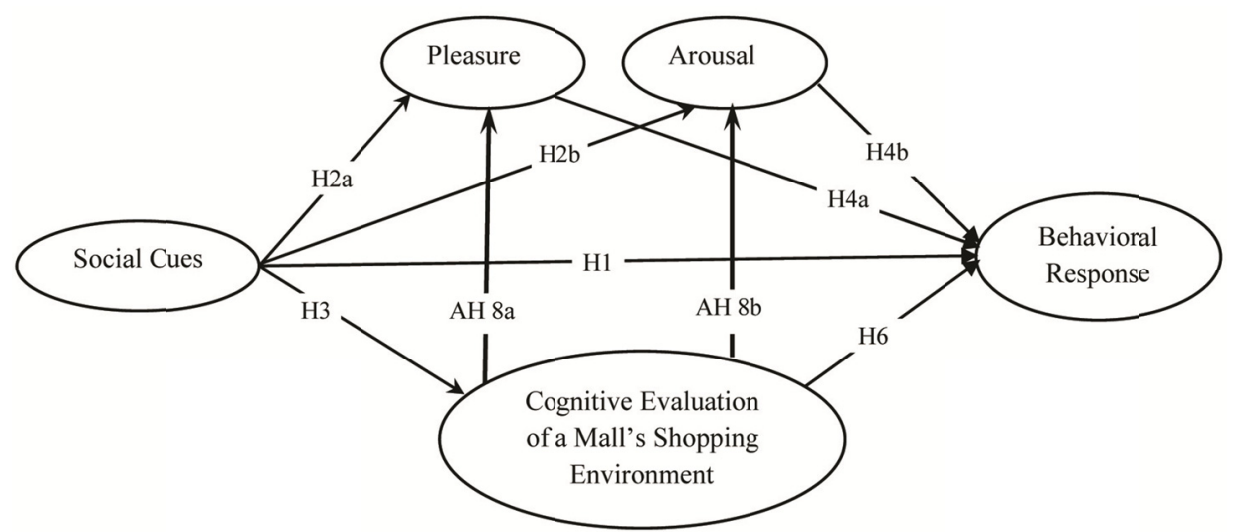

Figure 3. Model 2 (Alternative model) cognition-emotion mediated model

Note. *AH: Alternative Hypothesis. Hypotheses 5, 7, 9, and AH9 suggest mediation, thus, are not explicitly presented in the research conceptual models.

\subsection{Social Cues and Behavioral Response}

Social cues have been conceptualized as the human variables presenting in a store's environment, involving both personnel and other customers, alongside their attributes such as number, type and behavior (Baker, 1994). In line with this, several studies reported a direct link between customer-related and employee-related social cues and customers' behavioral responses. For instance, social interaction with other customers was found to positively affect customers' behavioral intention (Cetin \& Dincer, 2014) and approach-avoidance behaviors (Brocato et al., 2012). Customers show higher intentions to patronize stores providing higher levels of service personalisation (Hu \& Jasper, 2006). Positive effects were also evidenced for perceived human crowdedness on customers' unplanned purchases (Eroglu, Machleit, \& Barr, 2005; Li et al., 2009), intention to enter the store (Pan \& Siemens, 2011), time spent in the store and purchases made (Harrell, Hutt, \& Anderson, 1980). Accordingly, hypothesis H1 states that:

H1: The social cues of a mall's shopping environment have a significant positive effect on customers' behavioral response.

\subsection{Social Cues and Customers' Emotions and Cognition}

Mehrabian \& Russell (1974) introduced environments in general as emotion-triggering objects affecting individuals' emotional states. Therefore, studies adopting the M-R theoretical framework posit customers' surroundings (e.g., social cues) to affect how customers feel toward the environment, thereby, how they wouldbehaviorally respond to it.

Empirical studies in this extent provide evidence of the role of diverse social cues in stimulating customers' 
emotions. For instance, level of social match with other guests plays a critical role in eliciting guests' emotions in hotels (Jani \& Han, 2014). Staff appearance was found to affect customers' pleasure in restaurants (Ryu \& Jang, 2007). In shopping malls Raajpoot, Sharma, \& Chebat (2008) reported a positive link between favorable behaviors of employees and customers' emotions. The findings of Li et al. (2009) show a positive relationship between human crowdedness and customers' emotion of pleasure in hypermarket stores. Based on that, it is stated that:

H2: The social cues of a mall's shopping environment have a significant positive effect on customers' emotions of (a) pleasure and (b) arousal.

Several scholars have addressed the role of the social aspects of shopping environment in affecting customers' minds. For example, Hwang \& Han (2014) find customers' perceptions of others presenting in a service scape to positively affect customers' perceptions of country-club prestige. Customers tend to infer better evaluations to a service setting such as restaurants with higher levels of crowdedness compared to that with lower crowdedness levels (Tse, Sin, \& Yim, 2002). The findings of Baker et al. (1994) and Yan et al. (2011) show the effect of personnel in retail stores on the perceived quality of service provided. Accordingly, hypothesis H3 states that:

H3: The social cues of a mall's shopping environment have a significant positive effect on customers' cognitive evaluation of the mall's shopping environment.

\subsection{The Role of Emotions and Cognition in Social Cues-Behavioral Response Relationship}

Existing literature acknowledges the effect of customers' positive emotions in shopping environments on customers' behavioral responses. For instance, customers with positive emotions in retail environments showed higher intention to divulge positive word of mouth (Nyer, 1997), to buy more (Baker, 1992), and to spend more money and keep loyal (Lin \& Liang, 2011). The results of Ryu \& Jang (2007) and Raajpoot, Jackson, and Lefebvre (2013) suggest customers' emotions as mediating variables in social cues-customers' behavioral response relationship. The proceeding discussion leads to the following hypotheses:

H4: Customers' emotions of (a) pleasure and (b) arousal in a mall's shopping environment have a significant positive effect on their behavioral response.

H5: Customers' emotions of (a) pleasure and (b) arousal mediate the effect of the social cues of a mall's shopping environment on customers' behavioral response.

Bitner (1992) extends the traditional M-R model by incorporating customer cognitive response (e.g., beliefs) as another organism factor affecting customer response in servicescapes. Babin, Hardesty, \& Suter (2003) found that better customer cognitive inferences of price fairness formed on the basis of shopping environment cues to affect customers' patronage and purchase intentions positively. Wan, Poon, \& Chu (2014) reported a mediating role of perceived service quality in the relationship between perceived similarity of other customers and customers' behavioral intention. Accordingly, the following hypotheses are proposed:

H6: Better customers' cognitive evaluation of a mall's shopping environment has a significant positive effect on their behavioral response.

H7: Customers' cognitive evaluation of a mall's shopping environment mediates the effect of social cues on customers' behavioral response.

\subsection{The Interplay-Mediating Role of Emotions and Cognition}

Although customers' emotions and cognition may work in parallel in mediating the effect of shopping environment factors (e.g., social cues) on customers' behavioral responses (Chen \& Hsieh, 2011; Im \& Ha, 2011; Sweeney \& Wyber, 2002), some scholars reported an interactive mediation of both emotional and cognitive dimensions (Chebat \& Michon, 2003; Dennis et al., 2012; Kim \& Moon, 2009).

Zajonc \& Markus (1984) depict the emotional experience as simple as the cognition of having such experience. Thus, without a preceding cognitive activity, emotions can be experienced. Essentially, this is the core assumption of "affect as information" theory (Schwarz \& Clore, 1983), which posits emotions as inputs on which a customer's cognitive appraisal can be based. Empirically, Liu \& Jang (2009) concluded that customers' positive emotions elicited by dining atmospherics are positively related to perceived value. Moreover, the findings of Laroche, Teng, Michon, \& Chebat (2005) suggest an emotion-cognition hierarchy in the mediation of emotions and cognition in shopping environment-customer behavioral response relationship. Accordingly, the following hypotheses are stated:

H8: Customers' emotions of (a) pleasure and (b) arousal have a significant positive effect on customers' cognitive evaluation of a mall's shopping environment. 
H9: Customers' cognitive evaluation of a mall's shopping environment mediates the effect of customers' emotions of (a) pleasure and (b) arousal on their behavioral response.

The cognitive theory of emotions (Lazarus, 1991) posits customers' cognition as a necessary antecedent condition for emotions to elicit. Consisting with that, Hightower, Brady, \& Baker (2002) revealed a direct positive influence of customers' inferences of a servicescape's quality on their affective states. The findings of Kim \& Moon (2009) suggest the perceived service quality as a predictor to customer pleasure-feeling in restaurants. Chebat \& Michon (2003) found that the cognition-emotion flow of mediation better explain the impact of malls' ambient scent on shoppers' spending, compared to the emotion-cognition flow. More recently, Dennis et al. (2012) found customers' perception of the malls' shopping environment to positively affect their feelings, thereby behavioral responses. Therefore, this leads to the following alternative hypotheses (see figure 3):

AH8: Customers' cognitive evaluation of a mall's shopping environment has a significant positive effect on customers' emotions of (a) pleasure and (b) arousal

AH9: Customers' emotions of (a) pleasure and (b) arousal mediate the effect of customers' cognitive evaluation of a mall's shopping environment on their behavioral response.

\section{Methods}

\subsection{Research Sample and Data Collection Procedures}

The research population of this study consists of all shopping malls' customers in Jordan. Due to unavailability of a sampling frame, the data was collected from a convenient sample of shopping malls' customers using mall intercept technique. However, respondent selection was as random as possible. Particularly, the data collection was carried out in seven randomly selected shopping malls across different cities (e.g., Amman, Irbed, and Azzarqa). Also, the fieldwork took place at different times of the day throughout the weekdays and weekends to ensure a better representative sample in terms of demographic variables. Furthermore, a systematic procedure using a random interval was applied to recruit potential respondents. That is, every fifth adult shopper bypassing a certain point before the exit of the mall was invited to take part in the survey.

Throughout five weeks of fieldwork, 1417 questionnaires were distributed, of which 1281 were returned, indicating a response rate of $90 \%$. Furthermore, 253 questionnaires were discarded based on a filtering question and due to incomplete responses, yielding an effective response rate of $73 \%$.

\subsection{Measures and Questionnaire Piloting}

Apart from demographic profile section, all measurement scales of the research questionnaire were drawn from established research, but in some cases, they were adapted to fit the context of shopping malls. A filtering question "do you consider yourself as a regular customer to this shopping mall/ shop twice a month at least-" was included in order to ensure that the respondent is a regular mall customer. Social cues were measured using ten items relating to employees, other customers, and human crowdedness. Items of this construct were measured on a 7-point Likert scale. Customers' emotions of pleasure and arousal were captured using 12-item bipolar semantic differential scale originated by Mehrabian \& Russell (1974). Environmental quality scale of Fisher (1974) was employed to assess customers' cognitive evaluation of the mall's shopping environment. Fisher's scale consists of thirteen 7-point bipolar semantic differential items. Customers 'behavioral response was operationalized using ten items relating to money spent, time spent, unplanned buying, positive word of mouth, and re-patronage intention measured on a 7-point Likert scale. Measurement items and the sources from which they were adapted are shown in table (1).

Using parallel translation technique, the source research questionnaire was translated into Arabic (the first language in Jordan) by two independent professional translators. Translated questionnaires were then compared and considered to develop the final questionnaire. The final questionnaire was also subjected to academic and field piloting to assure comprehensiveness, clarity and appropriateness of the used measurement scales. It was then pre-tested with a convenient sample of 100 mall customers in order to check the validity and reliability of selected measures. The results of the pre-test study asserted the reliability of the measurement scales and the clarity and simplicity of the questions to respondents. 
Table 1. Questionnaire's constructs and items

\begin{tabular}{|c|c|c|}
\hline Constructs & Codes and Items & Sources \\
\hline Social Cues & $\begin{array}{l}\text { (S1) There are enough employees in the mall to service customers. } \\
\text { (S2) The employees are well dressed and appear neat. } \\
\text { (S3) The employees are friendly. } \\
\text { (S4) The employees are helpful. } \\
\text { (S5) Employees of this mall give customers personal attention. } \\
\text { (S6) I can identify with the typical customer who shops at this shopping mall. } \\
\text { (S7) The typical customers at this shopping mall are very much like me. } \\
\text { (S8) The mall is too busy during my shopping trip. } \\
\text { (S9) There are a lot of shoppers in the mall. } \\
\text { (S10) There is much traffic in the mall. }\end{array}$ & $\begin{array}{l}\text { Baker et al. (1994), } \\
\text { Chang et al. (2011) } \\
\text { Li ta al. (2009) } \\
\text { Raajpoot et al. (2008) }\end{array}$ \\
\hline Pleasure & $\begin{array}{l}\text { (Pl 1) Annoyed-Pleased, (Pl 2) Dissatisfied-Satisfied,(Pl 3) Unhappy-Happy, (Pl 4) Bored-Relaxed, (Pl } \\
\text { 5) Melancholic-Contented, (Pl 6) Despairing-Hopeful. }\end{array}$ & $\begin{array}{l}\text { Mehrabian \& Russell } \\
\text { (1974) }\end{array}$ \\
\hline Arousal & $\begin{array}{l}\text { (AR 1) Sluggish-Frenzied, (AR 2) Unaroused-Aroused, (AR 3) Sleepy-Wide-awake, (AR 4) Calm- } \\
\text { Excited, (AR 5) Relaxed-Stimulated, (AR 6) Dull-Jittery. }\end{array}$ & $\begin{array}{l}\text { Mehrabian \& Russell } \\
\text { (1974) }\end{array}$ \\
\hline $\begin{array}{l}\text { Cognitive Evaluation of the } \\
\text { Mall's Shopping } \\
\text { Environment }\end{array}$ & $\begin{array}{l}\text { (GOG1) Unattractive-Attractive, (GOG2) Tense-Relaxed, (GOG3) Uncomfortable-Comfortable, } \\
\text { (GOG4) Depressing-Cheerful, (GOG5) Closed-Open, (GOG6) Drab Colourful,,(GOG7) Negative- } \\
\text { Positive, (GOG8) Boring-Stimulating, (GOG9) Bad-Good, (GOG10) Unlively-Lively, ,(GOG11) Dull- } \\
\text { Bright, (GOG12) Unmotivating-Motivating, (GOG13) Uninteresting-Interesting. }\end{array}$ & Fisher (1974) \\
\hline
\end{tabular}

\section{Data Analysis and Findings}

\subsection{Preliminary Analysis and Data Normality}

The data screening and filtering resulted in a dataset of 1028 usable questionnaires carried forward for further analysis. Descriptive statistics (e.g., frequency, minimum values, and maximum values) confirmed that the data was complete and within the acceptable range. Skewness and kurtosis values for all measurement items were within the cut-off points (skewness $<3$ and kurtosis $<$ indicating a reasonable normal distribution of the data (Kline, 2005).

\subsection{Respondents' Demographic Profile}

Descriptive statistics indicated that there were $541(52.6 \%)$ females and 487 (47.4\%) out of 1028 respondents in total. The majority of respondents was single $683(66.4 \%)$, and was $20-29$ years old $637(62 \%)$. The vast majority 657 (63.9\%) of respondents had a Bachelor's degree. In terms of job, respondents were mainly students $450(43.8 \%)$ and privet sector employees 279 (27.1\%). And finally, the vast majority 854 (83.1\%) of respondents got less than 1000 JDs as monthly income. A detailed demographic profile of respondents is presented in table (2).

Table 2. Respondents' demographic profile

\begin{tabular}{llll}
\hline Variable & Category & Count & Percentage \% \\
\hline Gender & Male & 487 & 47.4 \\
& Female & 541 & 52.6 \\
& Total & 1028 & 100.0 \\
\hline Age & $15-19$ & 118 & 11.5 \\
& $20-24$ & 400 & 38.9 \\
& $25-29$ & 237 & 23.1 \\
& $30-34$ & 144 & 14.0 \\
& $35-39$ & 35 & 3.4 \\
& $40-44$ & 43 & 4.2 \\
& $45-49$ & 39 & 3.8 \\
& 50 and above & 12 & 1.2 \\
& Total & 1028 & 100.0 \\
\hline Marital Status & Single & 683 & 66.4 \\
& Married & 324 & 31.5 \\
& Divorced & 9 & 0.9 \\
& Widowed & 12 & 1.2 \\
& Total & 1028 & 100.0 \\
\hline
\end{tabular}




\begin{tabular}{llll}
\hline Education & Secondary & 144 & 14.0 \\
& Diploma & 76 & 7.4 \\
& Bachelor & 657 & 63.9 \\
Higher Education & 141 & 13.7 \\
Other & 10 & 1.0 \\
Total & 1028 & 100.0 \\
\hline Job & Student & 450 & 43.8 \\
& Unemployed & 98 & 9.5 \\
Private Sector Employee & 279 & 27.1 \\
Public Sector Employee & 77 & 7.5 \\
Business Owner & 90 & 8.8 \\
Other & 34 & 3.3 \\
Total & 1028 & 100.0 \\
\hline Income & 500 JDs* and less & 598 & 58.2 \\
& 501-999 JDs & 256 & 24.9 \\
1000-1499 JDs & 109 & 10.6 \\
1500-1999 JDs & 29 & 2.8 \\
2000-2499 JDs & 17 & 1.7 \\
2500 JDs and above & 19 & 1.8 \\
Total & 1028 & 100.0 \\
\hline
\end{tabular}

Note. $* 1 \mathrm{JD}=1.3$ US Dollar.

\subsection{Main Data Analysis}

Data was analysed using structural equation modelling with AMOS by following the two-step approach as suggested by Anderson \&d Gerbing (1988). First, the measurement model was validated and then the structural models were examined. The measurement model (the same for the two hypothesized structural models) was assessed and validated using confirmatory factor analysis CFA, followed by validity and reliability checks. Model fit were assessed using different fit indices including the comparative fit index CFI, the normed fit index NFI the Tucker Lewis index TLI, the incremental fit index IFI, and the root mean square error of approximation RMSEA. Cut-off values of (CFI > 0.92; NFI, TLI and IFI > 0.90; and RMSEA < 0.08) were considered to conclude a satisfactory model fit (Byrne, 2001; Hair, Anderson, Tatham, \& Black, 1998). The two competing structural models were then assessed, and ultimately the research hypotheses of the selected structural model were tested.

\subsection{Measurement Model}

The initial measurement model with five constructs, measured by 45 observed items was subjected to confirmatory factor analysis CFA. The model was mis-specified (CFI $=0.866, \mathrm{NFI}=.849 \mathrm{TLI}=0.858, \mathrm{IFI}=0.866$, RMSEA $=0.056$ ).

Guided by diagnostic statistics (e.g., loading values, residuals, and modification indices), areas of model misfit were identified and handled by removing measurement items with poor loadings and excessively high modification indices. Two items relating to social cues (S7 and S9), and one item relating to behavioral response (BEH3) showed poor loading values on their respective constructs (e.g., < .50) (Hair et al., 1998), and thus were dropped from further analytical steps. Moreover, error terms of highly related items with too high modification indices were allowed to correlate sequentially until an adequate model fit was achieved. The resulting measurement model showed a satisfactory model fit $(\mathrm{CFI}=0.940, \mathrm{NFI}=0.923$, TLI $=0.935, \mathrm{IFI}=0.940$, RMSEA $=0.057$ ). Results of CFA are presented in table (3).

\subsection{Validity and Reliability}

Constructs' validity was assessed in terms of both convergent and discriminant validity. Factor loadings and average variance extracted AVE were considered to conclude constructs' convergent validity (Hair, Anderson, Tatham, \& Black, 2006). Factor loadings for all observed items were above the recommend threshold value of $(0.50)$ (Hair et al., 1998) and ranged between (0.51) and (0.93). Values of average variance extracted for all constructs were within the suggested value of $>50 \%$ (Fornell \& Larcker, 1981) except for behavioral response (0.39). However, all the items relating to this construct showed sufficient factor loadings and the construct had very good scores in both Cronbach's alpha (0.87) and composite reliability (0.84) (see table 3).

Discriminant validity was assessed on the basis of inter-correlation values among constructs (Kline, 2005), and AVE compared to the values of squared correlations between respective constructs (Fornell \& Larcker, 1981). As shown in table (4), all inter-correlation values were within the recommended threshold value of $<0.85$ and 
ranged between (0.29) and (0.60). Moreover, the average variance extracted of each construct was higher than the squared correlation among the respective constructs (table 5), suggesting that the constructs are sufficiently distinct from each other. The Cronbach's alpha values and composite reliability scores of all constructs were above the recommended cut-off point of (0.70) ( Hair, Celsi, Money, Samouel, \& Page, 2011), confirming a good reliability. Results of scales' reliability are presented in table (3).

Table 3. CFA results and constructs' validity and reliability

\begin{tabular}{|c|c|c|c|c|c|c|c|}
\hline Constructs & $\begin{array}{l}\text { Items } \\
\text { retained }\end{array}$ & $\begin{array}{l}\text { Factor } \\
\text { loadings }\end{array}$ & $\begin{array}{l}\text { Items } \\
\text { retained }\end{array}$ & $\begin{array}{l}\text { Factor } \\
\text { loadings }\end{array}$ & $\begin{array}{l}\text { AVE } \\
\%\end{array}$ & CR & $\begin{array}{l}\text { Cronbach's } \\
\text { alpha }\end{array}$ \\
\hline \multirow{4}{*}{ Social cues } & $\mathrm{S} 1$ & 0.82 & S5 & 0.87 & \multirow{4}{*}{61} & \multirow{4}{*}{0.93} & \multirow{4}{*}{0.93} \\
\hline & $\mathrm{S} 2$ & 0.90 & S6 & 0.80 & & & \\
\hline & S3 & 0.60 & S8 & 0.65 & & & \\
\hline & $\mathrm{S} 4$ & 0.88 & $\mathrm{~S} 10$ & 0.66 & & & \\
\hline \multirow{3}{*}{ Pleasure } & P11 & 0.85 & $\mathrm{P} 14$ & 0.93 & \multirow{3}{*}{80} & \multirow{3}{*}{0.96} & \multirow{3}{*}{0.96} \\
\hline & $\mathrm{P} 12$ & 0.87 & $\mathrm{P} 15$ & 0.91 & & & \\
\hline & $\mathrm{P} 13$ & 0.91 & P16 & 0.88 & & & \\
\hline \multirow{3}{*}{ Arousal } & AR1 & 0.82 & AR4 & 0.83 & \multirow{3}{*}{65} & \multirow{3}{*}{0.92} & \multirow{3}{*}{0.93} \\
\hline & AR2 & 0.78 & AR5 & 0.76 & & & \\
\hline & AR3 & 0.89 & AR6 & 0.75 & & & \\
\hline \multirow{7}{*}{$\begin{array}{l}\text { Cognitive } \\
\text { evaluation of a } \\
\text { mall's shopping } \\
\text { environment }\end{array}$} & COG1 & 0.84 & COG8 & 0.91 & \multirow{7}{*}{81} & \multirow{7}{*}{0.98} & \multirow{7}{*}{0.98} \\
\hline & COG2 & 0.84 & COG9 & 0.91 & & & \\
\hline & COG3 & 0.89 & COG10 & 0.90 & & & \\
\hline & COG4 & 0.92 & COG11 & 0.91 & & & \\
\hline & COG5 & 0.90 & COG12 & 0.92 & & & \\
\hline & COG6 & 0.88 & COG13 & 0.90 & & & \\
\hline & COG7 & 0.92 & & & & & \\
\hline \multirow{5}{*}{$\begin{array}{l}\text { Behavioral } \\
\text { response }\end{array}$} & BEH1 & 0.51 & BEH7 & 0.83 & \multirow{5}{*}{39} & \multirow{5}{*}{0.84} & \multirow{5}{*}{0.87} \\
\hline & $\mathrm{BEH} 2$ & 0.52 & BEH8 & 0.66 & & & \\
\hline & BEH4 & 0.52 & ВЕН9 & 0.73 & & & \\
\hline & BEH5 & 0.55 & BEH10 & 0.73 & & & \\
\hline & BEH 6 & 0.51 & & & & & \\
\hline
\end{tabular}

Table 4. Inter-correlation matrix

\begin{tabular}{llllll}
\hline Construct & 1 & 2 & 3 & 4 & 5 \\
\hline 1. Social cues & 1.00 & 0.32 & 0.29 & 0.47 & 0.43 \\
2. Pleasure & & 1.00 & 0.38 & 0.60 & 0.46 \\
3. Arousal & & & 1.00 & 0.48 & 0.31 \\
4. Cognitive evaluation of the shopping environment & & & & & 1.00 \\
5. Behavioral response & & & & & 0.47 \\
\hline
\end{tabular}

Table 5. Construct validity

\begin{tabular}{llllll}
\hline Construct & 1 & 2 & 3 & 4 & 5 \\
\hline 1. Social cues & $\mathbf{0 . 6 1}$ & 0.10 & 0.08 & 0.22 & 0.18 \\
2. Pleasure & & $\mathbf{0 . 8 0}$ & 0.14 & 0.36 & 0.16 \\
3. Arousal & & & $\mathbf{0 . 6 5}$ & 0.23 & 0.11 \\
4.Cognitive evaluation of the shopping environment & & & & & $\mathbf{0 . 8 1}$ \\
5. Behavioral response & & & & & 0.22 \\
\hline
\end{tabular}

Note. Diagonal values represent average variance extracted for each construct. Off-diagonal values represent the variance shared (squared correlation) between constructs.

\subsection{Common Method Bias}

Common method bias was examined using the Harman's single-factor approach as suggested by Podsakoff, MacKenzie, Lee, \& Podsakoff (2003). That is, all the observed variables across all constructs were loaded into one single latent construct. The resulting single-factor model exhibited a model fit (Chi sq/df=18.406, CFI=0.687, 
$\mathrm{NFI}=0.675, \mathrm{TLI}=0.666, \mathrm{IFI}=0.687, \mathrm{RMSEA}=0.130$ ), which is much worse than the model fit of the measurement model (Chi sq $/ \mathrm{df}=4.394, \mathrm{CFI}=0.940, \mathrm{NFI}=0.923, \mathrm{TLI}=0.935, \mathrm{IFI}=0.940, \mathrm{RMSEA}=0.057$ ). Thus, common method bias does not seem to be a problematic issue in the present study.

\subsection{Structural Model and Hypotheses Testing}

Two competing structural models were portrayed and tested as hypothesized earlier. Each of the models: emotion-cognition mediated model and cognition-emotion mediated model consists of five latent variables measured by 42 retained observed items. The models were assessed and compared against each other on the basis of overall fitting indices. Assessing models' fit revealed that cognition-emotion model showed a slightly better fit to the data compared to the emotion-cognition model (table 6).This indicates that the cognition-emotion model is better in explaining the effect of social cues on customers' behavioral response.

Table 6. Structural models fit indices

\begin{tabular}{llllllll}
\hline Model & Chi sq (df) & Chi sq/df & CFI & NFI & TLI & IFI & RMSEA \\
\hline Emotion-cognition & $3439^{*}(796)$ & 4.320 & .941 & .925 & .936 & $\mathbf{. 9 4 1}$ & $\mathbf{. 0 5 7}$ \\
Cognition-emotion & $3359^{*}(796)$ & 4.220 & .943 & .927 & .938 & $\mathbf{. 9 4 3}$ & $\mathbf{. 0 5 6}$ \\
\hline
\end{tabular}

Note. * P-value $<.001$, df: degree of freedom.

Beta coefficients $(\beta)$ of structural paths, related probability values, and critical ratios (table 7) were examined to report the results of direct effects in the selected model. Beta coefficients are computed in AMOS based on the basic equation of regression: $Y_{\mathrm{i}}={ }_{0}+X_{\mathrm{i}}+e_{i}$, where $Y$ is the dependent variable, $X$ is the independent variable, ${ }_{0}$ is intercept of the line, is slope of the line, and $\mathrm{e}_{\mathrm{i}}$ is the error term associated with the ${ }_{\mathrm{i}}$ th observation (Malhotra, 2010).

Social cues had a significant positive effect on customers' behavioral response $(\beta=0.26, p<0.001)$, pleasure $(\beta$ $=0.09, p=.003)$, arousal $(\beta=0.11, p<0.001)$, and cognitive evaluation of the mall's shopping environment $(\beta=$ $0.41, p<0.001)$. Therefore, hypotheses one, two, and three were fully supported. Customers' emotion of pleasure $(\beta=0.25, p<0.001)$ but not arousal $(\beta=0.05, p=0.166)$ was found to have a significant positive effect on their behavioral response, suggesting a partial support for hypothesis four. A support was also reported for the effect of customers' cognitive evaluation of the mall's shopping environment on behavioral response $(\beta=0.19, p$ $<0.001)$, pleasure $(\beta=0.57, p<0.001)$, and arousal $(\beta=0.44, p<0.001)$. Hence, hypothesis six and alternative hypothesis eight were verified. Figure (4) shows the full structural model with beta coefficients of direct paths.

Table 7. Hypotheses testing-direct paths

\begin{tabular}{lllllll}
\hline \multicolumn{1}{c}{ Path } & & Hypothesis & $(\boldsymbol{\beta})$ & $\boldsymbol{P}$ & C.R. & Result \\
\hline Social Cues & $\longrightarrow$ Behavior & $\mathrm{H} 1$ & .26 & $* * *$ & 7.32 & Supported \\
Social Cues & $\longrightarrow$ Pleasure & $\mathrm{H} 2 \mathrm{a}$ & .09 & .003 & 3.00 & Supported \\
Social Cues & $\longrightarrow$ Arousal & $\mathrm{H} 2 \mathrm{~b}$ & .11 & $* * *$ & 3.34 & Supported \\
Social Cues & $\longrightarrow$ Cognition & $\mathrm{H} 3$ & .41 & $* * *$ & 12.07 & Supported \\
Pleasure & $\longrightarrow$ Behavior & $\mathrm{H} 4 \mathrm{a}$ & .25 & $* * *$ & 6.45 & Supported \\
Arousal & $\longrightarrow$ Behavior & $\mathrm{H} 4 \mathrm{~b}$ & .05 & .166 & 1.38 & Not supported \\
Cognition & $\longrightarrow$ Behavior & H6 & .19 & $* * *$ & 4.40 & Supported \\
Cognition & $\longrightarrow$ Pleasure & AH8a & .57 & $* * *$ & 18.06 & Supported \\
Cognition & $\longrightarrow$ Arousal & AH8b & .44 & $* * *$ & 12.70 & Supported \\
\hline
\end{tabular}

Note. $\beta$ : beta coefficient, P: probability value, ${ }^{* * *}: \mathrm{p}<.001$, C.R.: critical ratio, AH: alternative hypothesis

Mediation hypotheses were examined using Baron \& Kenny's (1986) approach . In addtion to that, direct and inderct effects among constructs were examined to identify mediation type (e.g., partial or full). The significance of inderct paths was concluded on the basis of bootsraping procedures using AMOS. The findings demonstrated a partial mediation for cognition and pleasure in the relationship between social cues and behavioral response. Therefore, a partial and full support was reported for hypothesis five and hypothesis seven respectvely. Pleasure but not arousal partialy mediated the effect of customers' cognition on their behavioral response, indicating a partial support to hypothesis nine. Results of mediation anlysis are presented in table (8). 
Table 8. Results of mediation test

\begin{tabular}{llll}
\hline Path & $\begin{array}{l}\text { Direct } \\
\text { mediator }\end{array}$ & $\begin{array}{c}\text { without } \\
\text { Indirect } \\
\text { mediator }\end{array}$ & $\begin{array}{l}\text { with } \\
\text { Indirect effect significance and } \\
\text { Result }\end{array}$ \\
\hline Soc-Cog-Beh & $.426^{*}$ & $.260^{*}$ & Significant (.001) Partial mediation \\
Soc-Pl-Beh & $.426^{*}$ & $.266^{*}$ & Significant $(.004)$ Partial mediation \\
Soc-Ar-Beh & $.426^{*}$ & $.267 *$ & Not significant $(.216)$ No mediation \\
Cog-Pl-Beh & $.349^{*}$ & $.188^{*}$ & Significant $(.001))$ Partial mediation \\
Cog-Ar-Beh & $.349^{*}$ & $.197 *$ & Not significant $(.216)$ No mediation \\
\hline
\end{tabular}

Note. *: $p<.001$. Soc: social cues, Cog: cognitive evaluation of the shopping environment, Pl: pleasure, Ar: arousal, Beh: behavioral response.

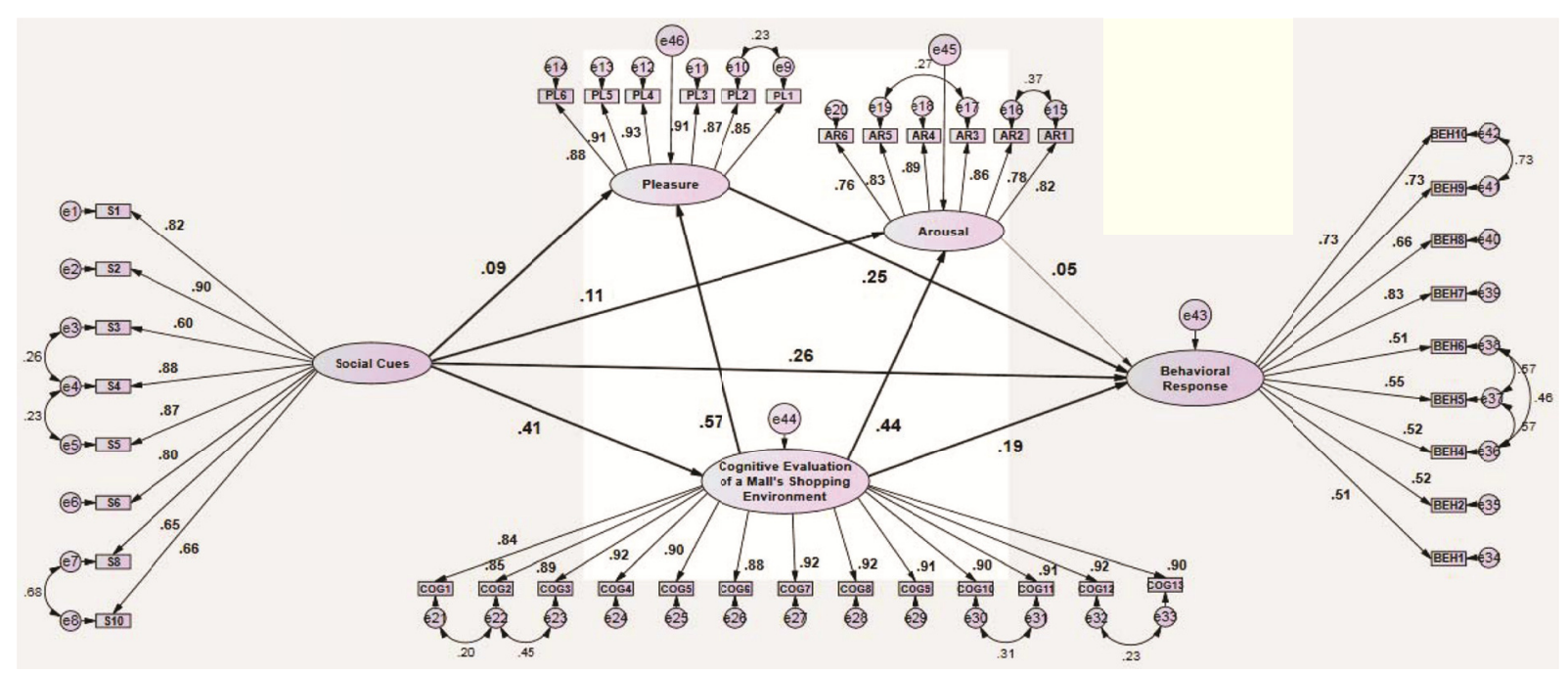

Figure 4. Structural model (alternative model)

Note. Chi Sq $(\mathrm{df})=3359$ (796), Chi Sq/df=4.220, CFI=.943, $\mathrm{NFI}=.927, \mathrm{TLI}=.938, \mathrm{IFI}=.943, \mathrm{RMSEA}=.056$.

\section{Discussion and Conclusion}

This study investigates the effect of the social cues of a shopping environment on customers' behavioral response through examining two competing models representing different kinds of two-step mediation in the context of shopping malls in Jordan. Each of the models consists of the same latent factors measured by the same observable items. However, they differ in terms of the direction of the mediation's flow based on two contrasting theories (e.g., emotion-cognition vs. cognition-emotion).

Models' fit assessment revealed that the cognition-emotion mediated model showed a slightly better fit compared to the emotion-cognition mediated model (lower Chi sq and Chi sq/DF; higher CFI, NFI, TLI, and IFI; and lower RMSEA). This overall result confirms the superiority of Lazarus's (1991) cognitive theory of emotions over affect as information theory (Schwarz \& Clore, 1983)in explaining the interplay mediation of emotions and cognition in social cue-customers' behavioral response relationship.

The results of hypotheses' testing demonstrated direct effects of social cues on customers' emotional, cognitive and behavioral responses. These findings have been evidenced in previous studies (Baker et al., 1994; Brocato et al., 2012; Cetin \& Dincer, 2014; Li et al., 2009; Mattila \& Wirtz, 2008; Pugh, 2001; Wan et al., 2014; Yan et al., 2011). For instance, Brocato et al. (2012) reported a direct effect of other customers on customers' approach-avoidance behavior in retail contexts. The findings of Ryu \& Jang (2007) suggested the facility's employees as a predictor of customers' emotions of pleasure and arousal in restaurants. Yan et al. (2011) found that formal dress of retail employees to positively associate with better inferences of service quality. However, social cues had more to do with customers' cognition $(\beta=0.41)$ compared to customers' emotions of pleasure $(\beta$ $=0.09)$ and arousal $(\beta=0.11)$. This can be attributed to the fact that human crowding which was included as a part of the social cues can have inverse effect on customers' feelings (Machleit et al., 2000).

In the second part (O-R) of the causal chain (S-O-R), customers' behavioral response was derived by their cognitive evaluations of the shopping environment and emotion of pleasure. This is consistent with the findings 
of previous research (Donovan et al., 1994a; Kim \& Moon, 2009; Novak, La Lopa, \& Novak, 2010; Ryu \& Jang, 2007; Sweeney \& Wyber, 2002). For instance, customers with higher levels of pleasure tend to spend more time in stores and make more unplanned purchases (Donovan et al., 1994b), and to show greater intention to revisit the store in the future (Kim \& Moon, 2009). Additionally, the results of Sweeney \& Wyber (2002) verify the positive effect of customers' emotions (e.g., pleasure) and cognitive evaluations (e.g., merchandise and service quality) on intended approach behavior.

Unexpectedly, no effect was noticed for arousal on behavioral response. This might be attributed to the conditional interaction between pleasure and arousal in deriving customers' behavioral response. That is, the effect of arousal (positive or negative) depends on whether the environment is pleasant or unpleasant (Mehrabian $\&$ Russell 1974). In the current study, customers were not considerably pleased $(\beta=0.09)$ with the environment, resulting in a non-significant effect of arousal on behavioral response.

Referring to the indirect paths in the model, a partial mediation for pleasure and cognition was reported in the relationship between social cues and behavioral response. This is congruent with findings by Lin \& Liang (2011) who found the social and physical environments to positively affect customers' behavioral intentions through positive emotions. It is also consistent with the findings of Wan et al. (2014) who reported an indirect effect of social cues (e.g., other customers) on customers' buying intention through a cognitive channel (e.g., perceived service quality). In terms of the interplay mediation of emotions and cognition, the later has a significant direct effect on customers' emotions of pleasure and arousal and indirect effect on behavioral response via pleasure. This suggests a cognition-emotion hierarchy of mediation in the effect, supporting the findings of Chebat and Michon (2003) and Dennis et al. (2012).

\section{Research Contributions and Implications}

The contribution of this research can be explained in terms of: firstly, this study contributes to extant literature by incorporating a cognitive aspect (e.g., cognitive evaluation of the mall's shopping environment) alongside with emotional states (e.g., pleasure and arousal) to understand the effect of holistic social cues on customers' behavioral responses in a (SOR)-based framework. Therefore, the results provided greater insights to the mechanism by which customer emotions and cognition mediate this effect. In this regard, previous studies addressing emotion and/or cognition as mediators in social cues-customer behavior relationship have been considerably limited to certain specific social cues such as crowding, employees, and customers (e.g., Jani \& Han, 2014; Mehta et al., 2013; Ryu \& Jang, 2007; Wan et al., 2014) rather than examining the holistic concept.

Secondly, uniquely this study simultaneously examines two competing scenarios of mediation in social cues-customer behavior relationship: the two contrasting theoretical perspectives of emotion-cognition-response and cognition-emotion-response. Interestingly, even in the few empirical studies investigating the presence of mediation effects, only one of the cognition-emotion or emotion-cognition hierarchies is considered (e.g., Kumar \& Kim, 2014; Raajpoot et al., 2013). Finally, from a methodological perspective, unlike the majority of previous studies (Brocato et al., 2012; Cho, 2001; Pan \& Siemens, 2011; Tse et al., 2002; Yan et al., 2011), the current study was carried in a realistic setting using mall intercept survey with actual customers.

The study also demonstrates important implications to practice. Practitioners need to be aware of the necessity to include social cues in their marketing toolbox. This becomes crucial when the focus is on achieving a market differentiation, since social cues (e.g., employees) are probably of the most sustainable and least imitable components of the shopping environment if compared to other ones such as design factors (e.g., interior design). Insights of whether cognition precedes emotions or vice versa can be helpful in leveraging the effect of social cues on customers' behavioral responses. For instance, in light of the findings reported in this study, it would be more beneficial for practitioner to focus on the cognitive implications of the social cues rather than its emotional implications.

\section{Limitations and Areas of Future Research}

The study is believed to have some limitations offering promising areas for further research. The weak convergent validity of the construct of behavioral response implies the need to consider a different measurement scale in future. Moreover, the findings of the current study are limited in terms of generlaisbilty due the fact that data was collected exclusively in shopping malls using a systematic mall intercept sampling. Therefore, future research is invited to examine the research model in other retailing and service contexts (e.g., superstores and restaurants) using probability sampling techniques (e.g., simple random).

In the present study, social cues were operationalized as a holistic construct involving different social dimensions: employees, other customers, and human crowding. A fruitful area of future research is then to examine the 
relative importance of each of the aforementioned dimensions in affecting customers' responses.

Prior research reported a moderating role for personal variables (e.g., demographics) and shopping orientations on customers' behavior in shopping environments (Andersson, Kristensson, Wästlund, \& Gustafsson, 2012; Chang et al., 2011; Kaltcheva \& Weitz, 2006). Thus, such personal and situational variables can be taken into consideration and applied to the hypothesized model as moderating variables in a future research. Finally, another promising area of research is to examine how the social cues can be utilized to enhance customers' cognitive and emotional experience from mall managers' standpoint (e.g., El-Adly, 2007).

\section{References}

Akroush, M. N., Abu-ElSamen, A. A., \& Jaradat, N. A. (2011). The influence of mall shopping environment and motives on shoppers' response: a conceptual model and empirical evidence. International Journal of Services and Operations Management, 10(2), 168-198. http://dx.doi.org/10.1504/ijsom.2011.042516

Anderson, J. C., \& Gerbing, D. W. (1988). Structural equation modeling in practice: A review and recommended two-step approach. Psychological Bulletin, 103(3), 411. http://dx.doi.org/10.1037/0033-2909.103.3.411

Andersson, P. K., Kristensson, P., Wästlund, E., \& Gustafsson, A. (2012). Let the music play or not: The influence of background music on consumer behavior. Journal of Retailing and Consumer Services, 19(6), 553-560. http://dx.doi.org/10.1016/j.jretconser.2012.06.010

Babin, B. J., Hardesty, D. M., \& Suter, T. A. (2003). Color and shopping intentions: The intervening effect of price fairness and perceived affect. Journal of Business Research, 56(7), 541-551. http://dx.doi.org/10.1016/S0148-2963(01)00246-6

Bagozzi, R. P. (1986). Principles of marketing management (2nd ed.). Chicago: Science Research Associates.

Baker, J., Grewal, D., \& Levy, M. (1992). An experimental approach to making retail store environmental decisions. Journal of Retailing, 68(4), 445. Retrived from http://www.journals.elsevier.com/journal-of-retailing

Baker, J., Grewal, D., \& Parasuraman, A. (1994). The influence of store environment on quality inferences and store image. Journal of the Academy of Marketing Science, 22(4), 328-339. http://dx.doi.org/10.1177/0092070394224002

Baker, J., Parasuraman, A., Grewal, D., \& Voss, G. B. (2002). The influence of multiple store environment cues on perceived merchandise value and patronage intentions. The Journal of Marketing, 66(April), 120-141. http://dx.doi.org/10.1509/jmkg.66.2.120.18470

Baron, R. M., \& Kenny, D. A. (1986). The moderator-mediator variable distinction in social psychological research: Conceptual, strategic, and statistical considerations. Journal of Personality and Social Psychology, 51(6), 1173-1182. https://doi.org/10.1037//0022-3514.51.6.1173

Bitner, M. J. (1992). Servicescapes: the impact of physical surroundings on customers and employees. The Journal of Marketing, 56(April), 57-71. https://doi.org/10.2307/1252042

Brocato, E. D., Voorhees, C. M., \& Baker, J. (2012). Understanding the influence of cues from other customers in the service experience: a scale development and validation. Journal of Retailing, 88(3), 384-398. http://dx.doi.org/10.1016/j.jretai.2012.01.006

Byrne, B. M. (2001). Structural equation modeling with AMOS: Basic concepts, applications, and programming. London: Lawrence Erlbuam Associates.

Cetin, G., \& Dincer, F. I. (2014). Influence of customer experience on loyalty and word-of-mouth in hospitality operations. Anatolia, 25(2), 181-194. http://dx.doi.org/10.1080/13032917.2013.841094

Chang, H. J., Eckman, M., \& Yan, R.-N. (2011). Application of the Stimulus-Organism-Response model to the retail environment: the role of hedonic motivation in impulse buying behavior. The International Review of $\begin{array}{llll}\text { Retail, Distribution and 233-249. } & \text { Consumer }\end{array}$ http://dx.doi.org/10.1080/09593969.2011.578798

Chebat, J. C., \& Michon, R. (2003). Impact of ambient odors on mall shoppers' emotions, cognition, and spending: A test of competitive causal theories. Journal of Business Research, 56(7), 529-539. http://dx.doi.org/10.1016/S0148-2963(01)00247-8

Chebat, J. C., \& Morrin, M. (2007). Colors and cultures: Exploring the effects of mall décor on consumer perceptions. Journal of Business Research, 60(3), 189-196. http://dx.doi.org/10.1016/j.jbusres.2006.11.003 
Chebat, J. C., Michon, R., Haj-Salem, N., \& Oliveira, S. (2014). The effects of mall renovation on shopping values, satisfaction and spending behavior. Journal of Retailing and Consumer Services, 21(4), 610-618. http://dx.doi.org/10.1016/j.jretconser.2014.04.010

Chen, H., \& Hsieh, T. (2011). The effect of atmosphere on customer perceptions and customer behavior responses in chain store supermarkets. African Journal of Business Management, 5(24), 10054-10066. https://doi.org/10.5897/ajbm10.608

Cho, S. (2001). Influence of Consumer Age and Clothing Type of Salesperson on Consumer Satisfaction with Salesperson's Performance. Virginia Polytechnic Institute and State University.

Dennis, C., Michon, R., Brakus, J. J., Newman, A., \& Alamanos, E. (2012). New insights into the impact of digital signage as a retail atmospheric tool. Journal of Consumer Behavior, 11(6), 454-466. http://dx.doi.org/10.1002/cb.1394

Donovan, R. J., \& Rossiter, J. R. (1982). Store atmosphere: an environmental psychology approach. Journal of Retailing, 58(1), 34-57. Retrived from http://www.journals.elsevier.com/journal-of-retailing

Donovan, R. J., Rossiter, J. R., Marcoolyn, G., \& Nesdale, A. (1994). Store atmosphere and purchasing behavior. Journal of Retailing, 70(3), 283-294. http://dx.doi.org/10.1016/0022-4359(94)90037-x

El-Adly, M. I. (2007). Shopping malls attractiveness: a segmentation approach. International Journal of Retail \& Distribution Management, 35(11), 936-950. http://dx.doi.org/10.1108/09590550710828245

Eroglu, S. A., Machleit, K. A., \& Barr, T. F. (2005). Perceived retail crowding and shopping satisfaction: the role of shopping values. Journal of Business Research, 58(8), 1146-1153. http://dx.doi.org/10.1016/j.jbusres.2004.01.005

Fisher, J. D. (1974). Situation-specific variables as determinants of perceived environmental aesthetic quality and perceived crowdedness. Journal of Research in Personality, 8(2), 177-188. http://dx.doi.org/10.1016/0092-6566(74)90019-1

Fornell, C., \& Larcker, D. F. (1981). Evaluating structural equation models with unobservable variables and measurement error. Journal of Marketing Research, 39-50. http:dx.doi.org/10.2307/3151312

Hair, J. F. J., Anderson, R. E., Tatham, R. L., \& Black, W. C. (1998). Multivariate Data Analysis (5th ed.). New Jersey: Prentice Hall.

Hair, J. F., Anderson, R. E., Tatham, R. L., \& Black, W. C. (2006). Multivariate Data Analysis (6th ed.). Upper Saddle River, New Jersey: Pearson-Prentice Hall.

Hair, J. F., Celsi, M. W., Money, A. H., Samouel, P., \& Page, M. J. (2011). Essentials of business research methods (2nd ed.). New York: M. E. Sharpe.

Harrell, G. D., Hutt, M. D., \& Anderson, J. C. (1980). Path analysis of buyer behavior under conditions of crowding. Journal of Marketing Research, XVII (February), 45-51. http:dx.doi.org/10.2307/3151115

Hightower, R., Brady, M. K., \& Baker, T. L. (2002). Investigating the role of the physical environment in hedonic service consumption: an exploratory study of sporting events. Journal of Business Research, 55(9), 697-707. http://dx.doi.org/10.1016/S0148-2963(00)00211-3

Hu, H., \& Jasper, C. R. (2006). Social cues in the store environment and their impact on store image. International Journal of Retail \& Distribution Management, 34(1), 25-48. http://dx.doi.org/10.1108/09590550610642800

Hwang, J., \& Han, H. (2014). Understanding Other Customer Perceptions in the Private Country Club Industry. Asia Pacific Journal of Tourism Research, 1-22. http://dx.doi.org/10.1080/10941665.2014.936476

Im, H., \& Ha, S. (2011). An exploration of the cognitive-affective model of satisfaction in a shopping context: A test of competing models. The Service Industries Journal, 31(13), 2273-2288. http://dx.doi.org/10.1080/02642069.2010.504983

Jacob, C., Guéguen, N., Martin, A., \& Boulbry, G. (2011). Retail salespeople's mimicry of customers: Effects on consumer behavior. Journal of Retailing and Consumer Services, 18(5), 381-388. http://dx.doi.org/10.1016/j.jretconser.2010.11.006

Jang, S. C. S., \& Namkung, Y. (2009). Perceived quality, emotions, and behavioral intentions: Application of an extended Mehrabian-Russell model to restaurants. Journal of Business Research, 62(4), 451-460. http://dx.doi.org/10.1016/j.jbusres.2008.01.038 
Jani, D., \& Han, H. (2014). Testing the moderation effect of hotel ambience on the relationships among social comparison, affect, satisfaction, and behavioral intentions. Journal of Travel \& Tourism Marketing, 31(6), 731-746. http://dx.doi.org/10.1080/10548408.2014.888967

Kaltcheva, V., \& Weitz, B. (2006). When Should a Retailer Create an Exciting Store Environment? Journal of Marketing, 70(1), 107-118. Retrieved from http://www.jstor.org/stable/30162076

Khraim, H. S., Khraim, A. S., Al-Kaidah, F. M., \& Al-Qurashi, D. R. (2011). Jordanian Consumer's Evaluation of Retail Store Attributes: The Influence of Consumer Religiosity. International Journal of Marketing Studies, 3(4), 105. https://doi.org/10.5539/ijms.v3n4p105

Kim, W. G., \& Moon, Y. J. (2009). Customers' cognitive, emotional, and actionable response to the servicescape: A test of the moderating effect of the restaurant type. International Journal of Hospitality Management, 28(1), 144-156. http://dx.doi.org/10.1016/j.ijhm.2008.06.010

Klassen, M. L., Clayson, D., \& Jasper, C. R. (1996). Perceived effect of a salesperson's stigmatized appearance on store image: an experimental study of student's perceptions. International Review of Retail, Distribution and Consumer Research, 6(2), 216-224. http://dx.doi.org/10.1080/09593969600000021

Kline, R. B. (2005). Principles and Practice of Structural Equation Modelling. New York: Guilford Press.

Koo, D. M., \& Ju, S. H. (2010). The interactional effects of atmospherics and perceptual curiosity on emotions and online shopping intention. Computers in Human Behavior, 26(3), 377-388. http://dx.doi.org/10.1016/j.chb.2009.11.009

Kumar, A., \& Kim, Y. K. (2014). The store-as-a-brand strategy: The effect of store environment on customer responses. Journal of Retailing and Consumer Services, 21(5), 685-695. http://dx.doi.org/10.1016/j.jretconser.2014.04.008

Laroche, M., Teng, L., Michon, R., \& Chebat, J. C. (2005). Incorporating service quality into consumer mall shopping decision making: a comparison between English and French Canadian consumers. Journal of Services Marketing, 19(3), 157-163. http://dx.doi.org/10.1108/08876040510596830

Lazarus, R. S. (1991). Emotion and adaptation. Oxford: Oxford University Press.

Leenders, M. A., Smidts, A., \& El Haji, A. (2016). Ambient scent as a mood inducer in supermarkets: The role of scent intensity and time-pressure of shoppers. Journal of Retailing and Consumer Services. http://dx.doi.org/10.1016/j.jretconser.2016.05.007

Li, J. G. T., Kim, J. O., \& Lee, S. Y. (2009). An empirical examination of perceived retail crowding, emotions, and retail outcomes. The Service Industries Journal, 29(5), 635-652. http://dx.doi.org/10.1080/02642060902720121

Li, M., Ma, Q., Zhao, X., \& Liu, R. (2012). Studies on the Relationship between Social Cues in the Servicescape and Customer Behavioral Intention. Paper presented at the Service Sciences (IJCSS), 2012 International Joint Conference Shanghai. https://doi.org/10.1109/ijcss.2012.56

Lin, I. Y., Baron, S., \& Daunt, K. (2016). Effects of visual servicescape aesthetics comprehension and appreciation on consumer experience. Journal of Services Marketing, 30(7). http://dx.doi.org/10.1108/JSM-08-2015-0258

Lin, J. S. C., \& Liang, H. Y. (2011). The influence of service environments on customer emotion and service outcomes. Managing Service Quality, 21(4), 350-372. http://dx.doi.org/10.1108/09604521111146243

Liu, Y., \& Jang, S. S. (2009). The effects of dining atmospherics: an extended Mehrabian-Russell model. International Journal of Hospitality Management, 28(4), 494-503. http://dx.doi.org/10.1016/j.ijhm.2009.01.002

Machleit, K. A., Eroglu, S. A., \& Mantel, S. P. (2000). Perceived retail crowding and shopping satisfaction: what modifies this relationship? Journal of Consumer Psychology, 9(1), 29-42.

Malhotra, N. K. (2010). Marketing research: An applied orientation (6th ed.). Upper Saddle River, N.J.: Pearson Education.

Mattila, A. S., \& Wirtz, J. (2008). The role of store environmental stimulation and social factors on impulse purchasing. Journal of Services Marketing, 22(7), 562-567. http://dx.doi.org/10.1108/08876040810909686

Mehrabian, A., \& Russell, J. A. (1974). An approach to environmental psychology. Cambridge: MIT Press.

Mehta, R., Sharma, N. K., \& Swami, S. (2013). The impact of perceived crowding on consumers' store 
patronage intentions: Role of optimal stimulation level and shopping motivation. Journal of Marketing Management, 29(7-8), 812-835. http://dx.doi.org/10.1080/0267257X.2012.729075

Michon, R., Yu, H., Smith, D., \& Chebat, J. C. (2008). The influence of mall environment on female fashion shoppers' value and behavior. Journal of Fashion Marketing and Management, 12(4), 456-468. http://dx.doi.org/10.1108/13612020810906128

Morrison, M., Gan, S., Dubelaar, C., \& Oppewal, H. (2011). In-store music and aroma influences on shopper behavior and satisfaction. Journal of Business Research, 64(6), 558-564. http://dx.doi.org/10.1016/j.jbusres.2010.06.006

Novak, C. C., La Lopa, J., \& Novak, R. E. (2010). Effects of Sound Pressure Levels and Sensitivity to Noise on Mood and Behavioral Intent in a Controlled Fine Dining Restaurant Environment. Journal of Culinary Science \& Technology, 8(4), 191-218. http://dx.doi.org/10.1080/15428052.2010.535756

Nyer, P. U. (1997). A study of the relationships between cognitive appraisals and consumption emotions. Journal of the Academy of Marketing Science, 25(4), 296-304. https://doi.org/10.1177/0092070397254002

Pan, Y., \& Siemens, J. C. (2011). The differential effects of retail density: An investigation of goods versus service settings. Journal of Business Research, 64(2), 105-112. http://dx.doi.org/10.1016/j.jbusres.2010.02.011

Podsakoff, P. M., MacKenzie, S. B., Lee, J. Y., \& Podsakoff, N. P. (2003). Common method biases in behavioral research: a critical review of the literature and recommended remedies. Journal of Applied Psychology, 88(5), 879. http://dx.doi.org/10.1037/0021-9010.88.5.879

Pugh, S. D. (2001). Service with a smile: Emotional contagion in the service encounter. Academy of management journal, 44(5), 1018-1027. https://doi.org/10.2307/3069445

Quartier, K., Vanrie, J., \& Van Cleempoel, K. (2014). As real as it gets: What role does lighting have on consumer's perception of atmosphere, emotions and behavior? Journal of Environmental Psychology, 39, 32-39. http://dx.doi.org/10.1016/j.jenvp.2014.04.005

Raajpoot, N. A., Jackson, A., \& Lefebvre, J. (2013). Non-verbal Customer-to-Customer Interaction in Retail Setting: An Investigation of Indirect Effects of Perceived Customer Similarity on Important Marketing Outcomes. Atlantic Marketing Journal, 2(1), 2.

Raajpoot, N. A., Sharma, A., \& Chebat, J. C. (2008). The role of gender and work status in shopping center patronage. Journal of Business Research, 61(8), 825-833. http://dx.doi.org/10.1016/j.jbusres.2007.09.009

Russell, J. A., \& Pratt, G. (1980). A description of the affective quality attributed to environments. Journal of Personality and Social Psychology, 38(2), 311. http://dx.doi.org/10.1037/0022-3514.38.2.311

Ryu, K., \& Jang, S. C. S. (2007). The effect of environmental perceptions on behavioral intentions through emotions: The case of upscale restaurants. Journal of Hospitality \& Tourism Research, 31(1), 56-72. https://doi.org/10.1177/1096348006295506

Schwarz, N., \& Clore, G. L. (1983). Mood, misattribution, and judgments of well-being: Informative and directive functions of affective states. Journal of Personality and Social Psychology, 45(3), 513. http://dx.doi.org/10.1037/0022-3514.45.3.513

Sherman, E., Mathur, A., \& Smith, R. B. (1997). Store environment and consumer purchase behavior: mediating role of consumer emotions. Psychology and Marketing, 14(4), 361-378. https://doi.org/10.1002/(sici)1520-6793(199707)14:4\%3C361::aid-mar4\%3E3.0.co;2-7

Shukla, P., \& Babin, B. J. (2013). Effects of consumer psychographics and store characteristics in influencing shopping value and store switching. Journal of Consumer Behavior, 12(3), 194-203. https://doi.org/10.1002/cb.1411

Söderlund, M. (2011). Other customers in the retail environment and their impact on the customer's evaluations of the retailer. Journal of Retailing and Consumer Services, 18(3), 174-182. http://dx.doi.org/10.1016/j.jretconser.2010.09.006

Sweeney, J. C., \& Wyber, F. (2002). The role of cognitions and emotions in the music-approach-avoidance behavior relationship. Journal of Services Marketing, 16(1), 51-69. http://dx.doi.org/10.1108/08876040210419415

Tantanatewin, W., \& Inkarojrit, V. (2016). Effects of color and lighting on retail impression and identity. Journal 
of Environmental Psychology, 46, 197-205. http://dx.doi.org/10.1016/j.jenvp.2016.04.015

Tse, A. C. B., Sin, L., \& Yim, F. H. K. (2002). How a crowded restaurant affects consumers' attribution behavior. International Journal of Hospitality Management, 21(4), 449-454. http://dx.doi.org/10.1016/S0278-4319(02)00035-X

Turley, L. W., \& Milliman, R. E. (2000). Atmospheric effects on shopping behavior: a review of the experimental evidence. Journal of Business Research, 49(2), 193-211. http://dx.doi.org/10.1016/S0148-2963(99)00010-7

Uhrich, S. (2011). Explaining non-linear customer density effects on shoppers' emotions and behavioral intentions in a retail context: The mediating role of perceived control. Journal of Retailing and Consumer Services, 18(5), 405-413. http://dx.doi.org/10.1016/j.jretconser.2011.06.002

Vieira, V. A. (2012). Stimuli-organism-response framework: A meta-analytic review in the store environment. Journal of Business Research. http://dx.doi.org/10.1016/j.jbusres.2012.05.009

Wakefield, K. L., \& Baker, J. (1998). Excitement at the mall: determinants and effects on shopping response. Journal of Retailing, 74(4), 515-539. https://doi.org/10.1016/s0022-4359(99)80106-7

Walsh, G., Shiu, E., Hassan, L. M., Michaelidou, N., \& Beatty, S. E. (2011). Emotions, store-environmental cues, store-choice criteria, and marketing outcomes. Journal of Business Research, 64(7), 737-744. http://dx.doi.org/10.1016/j.jbusres.2010.07.008

Wan, L., Poon, S. C., \& Chu, M. (2014). Perceived similarity of other customers on service experience. Hong Kong Institute of Business Studies Working Paper Series, paper 72. Retrieved from http://commons.ln.edu.hk/hkibswp/72

Yalch, R., \& Spangenberg, E. (1990). Effects of store music on shopping behavior. Journal of Services Marketing, 4(1), 31-39. http://dx.doi.org/10.1108/EUM0000000002577

Yan, R. N., Yurchisin, J., \& Watchravesringkan, K. (2011). Does formality matter?: Effects of employee clothing formality on consumers' service quality expectations and store image perceptions. International Journal of Retail \& Distribution Management, 39(5), 346-362. http://dx.doi.org/10.1108/09590551111130775

Zajonc, R. B., \& Markus, H. (1984). Affect and cognition: the hard interface. In C. E. Izard \& J. Kagan (Eds.), Emotions, cognition, and behavior (pp. 63-103). Cambridge Cambridge University Press.

Zajonc, R. B., \& Markus, H. (1985). Must all affect be mediated by cognition? Journal of Consumer Research, 12(3), 362-364. http://dx.doi.org/10.1086/208523

\section{Copyrights}

Copyright for this article is retained by the author, with first publication rights granted to the journal.

This is an open-access article distributed under the terms and conditions of the Creative Commons Attribution license (http://creativecommons.org/licenses/by/4.0/). 